\title{
Trichomonas Infection
}

National Cancer Institute

\section{Source}

National Cancer Institute. Trichomonas Infection. NCI Thesaurus. Code C35720.

An infection that is caused by Trichomonas. 